\title{
PERAN KEPALA SEKOLAH SEBAGAI ADMINISTRATOR DI SMP MUHAMMADIYAH 17 CIPUTAT
}

\author{
As'ad dan Fatimah \\ Dosen Program Studi Pendidikan Bahasa dan Sastra Indonesia Universitas Indraprasta PGRI \\ Email: asad.ptunu@gmail.com - fatimahifat4@gmail.com
}

\begin{abstract}
The purpose of this research is to analyze how the role of principal as administrator in Muhammadiyah 17 Ciputat Junior High School. The research uses qualitative approach and the method used is case study. Sources of data from the research is the principal as key informant (main source) and all teachers in Muhammadiyah 17 Ciputat Junior High School. The data collection procedure is done by interview, participant observation, and document analysis related to this research object. The results of the research findings reveal that there are three quite effective roles that the principal performs as an administrator: (1) planning school work programs, (2) running school organizational functions and (3) teacher task coordination.
\end{abstract}

Keywords: administration, planning, organizing, and coordination

\section{PENDAHULUAN}

Kepala sekolah merupakan pemimpin pendidikan yang sangat penting. Dikatakan sangat penting karena lebih dekat dan langsung berhubungan dengan pelaksana program pendidikan di sekolah yang dipimpinnya. Dapat dilaksanakan atau tidaknya suatu program pendidikan dan tercapai atau tidaknya tujuan pendidikan tentu sangat bergantung kepada kecakapan dan kebijakan kepala sekolah sebagai pemimpin pendidikan.

Peran dan fungsi utama kepala sekolah sebagai pemimpin di sekolah adalah menciptakan situasi pembelajaran, sehingga guru-guru dapat mengajar, dan muridmurid dapat belajar dengan baik. Dalam melaksanakan fungsi dan peran tersebut, kepala sekolah memiliki tanggung jawab ganda, yaitu melaksanakan administrasi sekolah, sehingga tercipta situasi pembelajaran yang baik, dan melaksanakan supervisi, sehingga kemampuan guru-guru meningkat dalam membimbing pertumbuhan muridmuridnya.

Sebagai ujung tombak di lembaga yang dipimpinnya, kepala sekolah harus mampu membangun kerja sama dengan guru. Berkerja sama dengan guru merupakan faktor yang sangat penting karena keberhasilan suatu proses pendidikan di sekolah dipengaruhi oleh kecakapan kepala sekolah dalam mengorganisasikan guru. Hal tersebut tentu akan meningkatkan kemampuan dan kecakapan guru dalam menjalankan tugas dan fungsinya sebagi pendidik. Mengingat guru adalah insan terdidik, 
intelektualitas, dan mempunyai arah pandang yang sistematis, jika kemampuan dan potensi guru dikembangkan tentu akan memilki nilai manfaat yang lebih luas dan baik. Ini menjadi peluang bagi kepala sekolah untuk mengembangkan potensi-potensi yang belum tereksplor yang dimiliki guru.

Salah satu tugas pokok kepala sekolah yang sangat penting dalam menjalankan kegiatan sekolah adalah kepala sekolah sebagai administrator. Sebagai administrator, kepala sekolah dituntut piawai dalam memanfaatkan sumber daya yang ada, khususnya guru. Mengingat guru merupakan unsur strategik untuk kelangsungan pengembangan organisasi dan eksistensi sekolah. Indikator keberhasilan kepala sekolah sebagai administrator salah satunya ia mampu melibatkan guru-guru dalam pengelolaan dan aktivitas-aktivitas sekolah, seperti membuat perencanaan program sekolah, mengorganisasikan guru secara tepat, dan mengkoordinasikan tugas guru.

Pada pra observasi di sekolah tersebut, ada hal-hal yang menarik dan unik untuk diteliti. Dengan mengamati kondisi sekolah dan lingkungan sekolah yang sederhana, terlihat semangat kekeluargaan di sekolah tersebut sangat terasa. Hubungan kepala sekolah dengan guru, petugas tata usaha, petugas keamanan, petugas perpustakaan, dan peserta didik sangat baik. Suasana Iklim kerja yang efektif, menopang, dan saling melengkapi terlihat jelas.

Peneliti semakin tertarik untuk mendalami penelitian. Dengan melakukan pengamatan dan mewawancarai kepala sekolah dan guru senior, peneliti menyimpulkan bahwa hal-hal di atas dapat terwujud dengan baik tentu tidak lepas dari peran kepala sekolah sebagai administrator di sekolah tersebut. Sebagai administrator, kepala sekolah menjalankan berbagai kegiatan, seperti rapat kerja yang dilaksanakan rutin setiap akhir semester, mengadakan seminar tentang pengajaran internal sekolah, forum profesionalisme guru yang rutin diadakan setiap bulan, forum komunikasi dan silaturrahim mingguan, rapat evaluasi kinerja guru bulanan, dan lain sebagainya. Tentu hal tersebut merupakan langkah-langkah membangun kerja sama tim atau guru yang efektif, sehingga, peran kepala sekolah sebagai administrator di sekolah tersebut dapat terlaksana dengan baik.

Berdasarkan uraian di atas, dapat disimpulkan bahwa kepala sekolah sebagai administrator harus mampu membuat perencanaan program-program sekolah, mengorganisasikan guru, dan koordinasi dengan guru. 


\section{TINJAUAN PUSTAKA}

Di sekolah yang dipimpinnya, kepala sekolah memiliki tanggung jawab ganda, yaitu 1) melaksanakan administrasi sekolah sehingga tercipta situasi pembelajaran yang baik, 2) dan melaksanakan supervisi, sehingga kemampuan guru-guru meningkat dalam membimbing pertumbuhan murid-muridnya. Dalam pandangan Mike M. Milstein dan James A. Belasco (2010:191) berpendapat bahwa administration is used to designate the process (cycle of events) engaged in by all the members of the formal organization to direct and control the activities of the members of the organization. Pendapat yang sama juga disampaikan oleh William B. Castetter (2001:474) bahwa administrator is an indispensable ingredient for developing a compencation plan for administrative personnel.

Menurut pendapat Syaiful Sagala (2009:21) bahwa secara teoritik pengertian administrasi adalah melayani secara intensif, sedangkan secara etimologis, administrasi dalam bahasa inggris "administer" yaitu kombinasi dari kata latin yang terdiri dari kata "ad" dan "ministrare" yang berarti "to serve" yaitu melayani, membantu atau mengarahkan, dan memenuhi. Ngalim Purwanto (2012:3-4) berpendapat administrasi pendidikan adalah segenap proses pengerahan dan pengintegrasian terhadap sesuatu, baik personel, spiritual, maupun material yang bersangkut paut dengan tujuan pendidikan. Di dalam proses administrasi pendidikan, segenap usaha orang-orang yang terlibat di dalam proses pencapaian tujuan pendidikan itu diintegrasikan, diorganisasi, dan dikoordinasi secara efektif dan semua materi yang diperlukan dan yang telah ada dimanfaatkan secara efisien. Dadang Suharda (2010:30) berpendapat administrasi pendidikan adalah disiplin ilmu yang mempelajari usaha kerja sama dengan melibatkan segenap sumber daya yang ada, untuk mengembangkan potensi peserta didik dalam mencapai tujuan pendidikan secara efektif dan efisien.

Sebagai kepala sekolah yang memiliki peran sebagai administrator pendidikan bertanggung jawab terhadap kelancaran pelaksanaan pendidikan dan pengajaran di sekolahnya. Oleh kerena itu, untuk dapat melaksanakan tugasnya dengan baik, kepala sekolah hendaknya memahami, menguasai dan melaksanakan kegiatan-kegiatan yang berkenaan dengan fungsi atau perannya sebagai administrator pendidikan. 
Dari pendapat para ahli di atas dapat disimpulkan bahwa setiap kegiatan administrator mengandung di dalamnya fungsi-fungsi perencanaan, pengorganisasian, pengkoordinasian, pengawasan, kepegawaian, dan pembiayaan. Sebagai adaministrator, kepala sekolah hendakanya mampu mengaplikasikan fungsi-fungsi tersebut ke dalam pengelolaan sekolah yang dipimpinnya.

1. Membuat perencanaan sekolah.

Salah satu fungsi utama yang menjadi tanggung jawab kepala sekolah sebagai administrator adalah membuat atau menyusun rencana program sekolah. Tanpa perencanaan maupun planning, pelaksanaan suatu kegiatan akan mengalami kesulitan, dan bahkan mungkin juga kegagalan (Ngalim Purwanto, 2012:106)

Alex Miller (1998:48) berpendapat Planning is the equivalent to strategic programming for organization. Gari Dessler (1997:61) berpendapat planning is process of setting goals and courses of action, developing rules an procedures, and forecasting future outcomes. Menurut pendapat Yusuf Enoch, (dalam Soebagio Atmodiwirio, 2000:77) perencanaan adalah suatu proses mempersiapkan hal-hal yang akan dikerjakan pada waktu yang akan datang untuk mencapai suatu tujuan yang telah ditetapkan terlebih dahulu. Menurut pendapat Joel G. Seigel dan Jae K. Shim(dalamIrham Fahmi, 2011:19) bahwa perencanaan adalah memilih tujuan jangka pendek dan panjang serta merencanakan teknik dan strategi untuk mencapai tujuan tersebut.

Dari pendapat para pakar di atas, dapat disimpulkan bahwa, perencanaan adalah membuat dan merumuskan target-target sekala prioritas secara matang dengan metode, dan teknik yang tepat, serta mengkaji berbagai resiko-resiko yang dihadapi dengan solusi yang sudah disiapkan, dan menentukan aparat atau sumber daya yang ada untuk mencapai tujuan di masa yang akan datang. Perencanaan memiliki peran penting dan mendasar, karena perencanaan melihat jauh ke dapan dalam mewujudkan cita-cita dan keinginan yang diharapkan bersama.

Adapun langkah-langkah dalam membuat perencanaan sebagai berikut: a) menentukan dan merumuskan tujuan yang hendak dicapai, b) meneliti masalah-masalah atau pekerjaan-pekerjaan yang akan dilakukan, c) mengumpulkan data dan informasi yang diperlukan, d) menentukan tahap-tahap atau rangkaian tindakan, e) merumuskan bagaimana masalah-masalah tersebut akan dipecahkan, dan bagaimana pekerjaan- 
pekerjaan itu akan diselesaikan (Ngalim Purwanto, 2012:15). Adapun syarat-syarat dalam menyusun perencanaan sebagai berikut: a) perencaan harus didasarkan atas tujuan yang jelas, b) bersifat sederhana, realistis dan praktis, c) terinci, memuat segala uraian, serta klasifikasi kegiatan, dan rangkaian tindakan sehingga mudah dipedomani dan dijalankan, d) memiliki fleksibilitas, sehingga mudah disesuaikan dengan kebutuhan, serta kondisi, dan situasi sewaktu-waktu, e) terdapat perimbangan antara bermacam-macam bidang yang akan digarap dalam perencanaan itu, menurut urgensinya masing-masing, f) diusahakan adanya penghematan tenaga, biaya, dan waktu, serta kemungkinan penggunaan sumber-sumber daya dan dana yang tersedia dengan sebaik-baiknya, g) diusahakan agar sedapat mungkin tidak terjadi adanya duplikasi pelaksanaan.

Terkait dengan teori perencanaan yang sudah dijelaskan di atas, dapat disimpulkan bahwa, perencanaan merupakan unsur penting dan strategis yang memberikan arah pijakan dalam pelaksanaan kegiatan untuk mencapai tujuan atau sasaran yang dikehendaki. Dalam bidang pendidikan, perencanaan merupakan salah satu faktor kunci efektifitas keterlaksanaan kegiatan-kegiatan pendidikan, untuk mencapai tujuan pendidikan yang diharapkan sesuai dengan tingkat atau jenjangnya. Dalam ranah sekolah, kepala sekolah selaku administrator dituntut memiliki kemampuan dan wawasan yang luas agar dapat membuat perencanaan sekolah dengan menghasilkan program-program yang berpusat pada murid, mutu, fleksibel dan sesuai dengan harapan serta kebutuhan masyarakat setempat, sehingga perencanaan yang telah dibuat bersama dapat dijadikan sebagai arah kejelasan dalam melaksanakan kegiatan sekolah.

2. Menjalankan fungsi organisasi.

Organisasi merupakan bagian yang tak terpisahkan dari kehidupan manusia. Sepanjang hidup, manusia telah mengembangkan diri dengan orang lain untuk mencapai tujuan bersama. Namun tidak semua orang sadar apa yang mereka lakukan sebenarnya telah menjalankan fungsi dan tujuan berorganisasi. Di bawah ini akan dijelaskan pengertian organisasi yang dikemukakan oleh para pakar sebagai berikut:

Gibson, Ivancevich dan Donnelly (1997:4) berpendapat organisasi is a coordinated unit consisting of at last two people who function to achieve a common gaol or set of goal. Pendapat Dimock (dalam M. Anton Athoillah, 2010:170) 
organization is the systematic bringing together of interdependent part to form a unified whole through which authority, coordination and control may be exrcised to achive a given purpose. Pendapat Edgar Schein (dalam Soebagio Atmodiwirio, 2010:101) organisasi adalah koordinasi yang rasional dari aktivitas-aktivitas sejumlah orang untuk mencapai beberapa tujuan yang jelas melalui pembagian kerja, dan fungsi, serta melalui jenjang wewenang dan tanggung jawab. Yati Siti Mulyati dan Aan Komariah berpendapaat pengorganisasian adalah proses mengatur, mengalokasikan dan mendistribusikan pekerjaan, wewenang, dan sumber daya antara anggota organisasi untuk mencapai tujuan organisasi. Syaiful Sagala (2012:95) bependapat mengorganisasikan berarti: (1) menentukan sumber daya dan kegiatan yang dibutuhkan untuk mencapai tujuan organisasi, (2) merancang dan mengembangkan kelompok kerja yang berisi orang yang mempu membawa organisasi pada tujuan, (3) menunggaskan seseorang atau kelompok orang dalam suatu tanggung jawab dan fungsi tertentu, (4) mendelegasikan wewenang kepada individu yang berhubungan dengan keluwesan melaksankan tugas.

Menurut pendapat para ahli di atas, dapat disimpulkan bahwa, organisasi memiliki dua fungsi penting, pertama sebagai wadah sekelompok orang yang menggabungkan diri dengan suatu ikatan norma, peraturan, ketentuan dan kebijakan yang telah dirumuskan bersama, kedua organisasi sebagai alat bekerja sama, saling memberi dan menerima serta hubungan timbal balik untuk merealisasikan maksud (purpose), sasaran (objevctive), dan tujuan (goal)

Dalam mewujudkan efektifitas struktur organisasi, ada lima prinsip struktural yang harus difungsikan dengan baik sebagai berikut: a) prinsip pembagian kerja, yaitu dengan adanya spesialisasi atau ahlinya, merupakan langkah-langkah paling baik dalam memanfaatkan orang untuk dapat menjalankan tugasnya dengan efektif dan efisien, b) prinsip satu arah, yaitu sebuah keharusan menunjuk top manager untuk mengkoordinasikan aktivitas-aktivitas yang berkaitan, mengingat komplekstisitas pembagian kerja, sehingga tidak terjadi duplikasi dalam menjalankan perkerjaan, c) prinsip sentralisasi, yaitu menciptakan keseimbangan antara sentralisasi dengan desentralisasi. Keseimbangan tersebut tidak dapat ditentukan tanpa memperhatikan kecakapan para manajer yang ditunjuk untuk mengoordinasi departemen, d) prinsip otoritas dan tanggung jawab, yaitu perlu ada kaitan antara tanggung jawab para 
manajer dan otoritas yang mereka lakukan. Sudah menjadi pengakuan dasar, bahwa apabila manajer memberikan pengarahan aktivitas bawahan, maka ia harus dilimpahi hak untuk memberi perintah dan otoritas untuk menuntut ketaatan, e) prinsip rantai komando, yaitu rantai bertingkat dari atasan yang memegang peranan otoritas tertinggi, sampai dengan hierarki yang paling rendah. Komunikasi dari herarki yang paling rendah harus melewati setiap atasan dalam rantai komando, dan sebaliknya, komunikasi dari puncak atasan harus melewati setiap bawahan sampai komunikasi tersebut mencapai tingkat kesesuaian (Siswanto, 2000:98-99)

Prinsip-prinsip pengorganisasian adalah terbaginya semua tugas dalam berbagia unsur organisasi secara proporsional. Dengan kata lain, pengorganisasian yang efektif adalah membagi habis dan menstrukturkan tugas-tugas ke dalam sub-sub atau komponen-komponen organisasi. Langkah-langkah mendasar secara beruntun dalam mengorganisasi program sekolah adalah menentukan tugas, menentukan parameter (alat ukur) waktu dan kebutuhan, menentukan jabatan dan tanggung jawab, merinci hubungan wewanang, merinci hubungan kepengawasan, merinci hubungan komunikasi, identifikasi kebutuhan koordinasi, dan menyusun penetapan kriteria penilaian kerja, sehingga semua tugas dapat dikerjakan sesuai kewenangannya masing-masing.

3. Koordinasi sekolah.

Menurut Eka Prihatin (2011:14) adanya bermacam-macam tugas atau pekerjaan yang dilakukan oleh pendidik dan tenaga kependidikan, tentu memerlukan adanya koordinasi dari kepala sekolah. Adanya koordinasi yang baik dapat menghindarkan kemungkinan terjadinya persaingan yang tidak sehat, dan atau kesimpangsiuran dalam tindakan. Dengan koordinasi yang baik, semua bagian, dan personel dapat bekerja sama menuju ke satu arah tujuan yang telah ditetapkan. Pendapat Garri Dessler (2001:206) coordination is the process of achieving unity of action among interpendent activities. Lebih lanjut, Garri Dessler (2011:206) berpendapat coordination is required whenever two or more interpendentn individuals, group or department must work together to achieve a common goal. Husaini Usman (2006:363) berpendapat koordinasi adalah proses mengintegrasikan (memadukan), mensinkronisasikan, dan menyederhanakan pelaksanaan tugas yang terpisah-pisah secara terus menerus untuk mencapai tujuan secara efektif dan efisien. Yati Siti Mulyati dan Aan Komariah (2006:96) berpendapat: koordinasi atau pengendalian adalah proses 
untuk memastikan aktivitas sebenarnya sesuai dengan aktivitas yang direncanakan sebelumnya. Proses pengendalian atau koordinasi melibatkan beberapa elemen yaitu: (a) menetapkan standar kerja, (b) mengukur kerja, (c) membandingkan unjuk kerja dengan standar yang telah ditetapkan, (d) mengambil tindakan korektif saat terditeksi penyimpangan.

Dari penjelasan para ahli di atas dapat disimpulkan bahwa koordinasi adalah kerja sama yang berimbang dan hubungan yang harmonis, serta produktif antara pimpinan dengan personil-personil organisasi yang dipimpinnya dalam mengendalikan, dan mengintegrasikan tugas-tugas yang telah ditetapkan bersama, sehingga tugas-tugas tersebut dapat dijalankan dengan baik, efektif, dan efisen, serta dapat mengatasi kemungkinan adanya duplikasi dalam tugas, ketidakseimbangan dalam berat dan ringannya pekerjaan, dan kesimpangsiuran dalam menjalankan tugas, dan kewajiban.

Dalam memudahkan untuk memahami teori-teori yang sudah dipaparkan di atas terkait peran kepala sekolah sebagai administrator, dengan sub fokus sebagai berikut: 1) membuat perencanaan sekolah, 2) menjalankan fungsi organiasasi, dan 3) koordinator sekolah, dapat disimpulkan dengan tabel di bawah ini:

Tabel 1. Peran dan tugas kepala sekolah sebagai administrator

\begin{tabular}{|c|c|}
\hline \multicolumn{2}{|c|}{ Kepala Sekolah } \\
\hline Tugas & Peran \\
\hline $\begin{array}{l}\text { Perencanaan: } \\
\text { - } \quad \text { Menetapkan tujuan organisasi sekolah. } \\
\text { - } \quad \text { Menetapkan strategi pengembangan dan } \\
\text { teknik. } \\
\text { - } \quad \text { Prosedur, sistem, metode, dan anggaran. } \\
\text { - } \quad \begin{array}{l}\text { Menentukan standarisasi pencapaian } \\
\text { tujuan. }\end{array}\end{array}$ & $\begin{array}{l}\text { Mengambil keputusan: } \\
\text { - } \quad \text { Mengadakan koreksi, evaluasi dan } \\
\text { perbaikan. } \\
\text { - } \quad \text { Menentukan alokasi sumber daya. } \\
\text { - } \quad \text { Rapat dalam pengambilan keputusan rutin, } \\
\quad \text { dan khusus. } \\
\text { - } \quad \text { Memilih info terbaik. }\end{array}$ \\
\hline $\begin{array}{ll}\text { Mengorganisasikan: } \\
\text { - } & \text { Membagi tugas atau pekerjaan. } \\
\text { - } & \text { Menentukan, dan menempatkan } \\
& \text { sumber daya manusia (SDM) yang } \\
& \text { tepat dalam menjalankan tugas. } \\
\text { - } & \text { Pendelegasian wewenang dalam } \\
\text { menjalankan tugas. } \\
\text { - } \quad \text { Kempampuan menyusun job } \\
\text { description (penjabaran kerja). } \\
\text { - } \quad \text { Mengambil keputusan. }\end{array}$ & $\begin{array}{l}\text { Pengumpul dan pendristibusian info: } \\
\text { - } \quad \text { Info intern (info manajemen organisasi } \\
\text { - } \quad \text { Infolah). } \\
\quad \text { lain). } \\
\text { - } \quad \text { Info untuk strategi, kebijakan, program } \\
\quad \text { kerja dan anggaran. } \\
\text { - } \quad \text { Pengembangan organisasi sekolah. }\end{array}$ \\
\hline \begin{tabular}{ll}
\multicolumn{2}{l}{ Koordinator: } \\
- & Komunikasi. \\
- & Mengarahkan dan motivasi. \\
- & Penyelesaian konflik
\end{tabular} & $\begin{array}{l}\text { Mediator: } \\
\text { - } \quad \text { Pihak intern (penghubung antara personal } \\
\text { sekolah). } \\
\text { - } \quad \text { Pihak ekstern (penghubungan antar } \\
\text { sekolah, pemerintah (dinas pendidikan) dan } \\
\text { institusi-institusi terkait. }\end{array}$ \\
\hline
\end{tabular}




\section{METODE}

Penelitian ini menggunakan pendekatan kualitatif dan metode yang digunakan studi kasus (case study). Dalam pengumpulan data, peneliti menggunakan beberapa teknik yaitu: a) observasi yaitu pengamatan secara mendalam terhadap objek penelitian, b) wawancara yaitu peneliti mewawancarai kepala sekolah sebagai key informan atau sumber utama, guru senior, dan tenaga kependidikan, c) angket daftar pertanyaan yang diberikan kepada stakeholders atau pelaku pendidikan di sekolah tersebut.

\section{HASIL DAN PEMBAHASAN}

Salah satu fungsi utama yang menjadi tanggung jawab kepala sekolah sebagai administrator adalah membuat atau menyusun rencana program sekolah. Tanpa perencanaan maupun planning, pelaksanaan suatu kegiatan akan mengalami kesulitan, dan bahkan mungkin juga kegagalan. Pada objek penelitian di SMP Muhammadiyah 17 Ciputat terdapat program workshop atau rapat kerja yang dilaksanakan setiap akhir semester dan pada ajaran baru. Dalam rapat kerja yang dilaksanakan di internal sekolah maupun eksternal sekolah membahas mengenai evaluasi program-program sekolah yang telah dirumuskan sebelelumnya, memperbaiki dan menyempurnakan programprogram sekolah yang belum terlaksana secara optimal, dan merumuskan programprogram baru baik yang terkait dengan kegiatan akademik maupun program non akademik. Adapaun program-program akademik seperti melengkapi sarana dan prasarana yang menunjang kegiatan pembelajaran, meingikutsertakan siswa dan siswi pada kegiatan perlombaan di wilayah Ciputat dan sekitarnya, dan lain sebagainya. Sedangkan program-progam non akademik seperti memaksimalkan kegiatan ektrakulikuler seperti pencak silat, pramuka drumband, marawais, dan lain sebagainya.

Temuan penelitan tersebut di atas sesuai dengan pendapat ahlibahwa perencanaan adalah suatu proses mempersiapkan hal-hal yang akan dikerjakan pada waktu yang akan datang untuk mencapai suatu tujuan yang telah ditetapkan terlebih dahulu (Yusuf Enochdalam Soebagio Atmodiwirio, 2000:77). Hal yang senada juga kemukakan oleh Joel G. Seigel dan Jae K. Shim(dalamIrham Fahmi, 2011:19) bahwa perencanaan adalah memilih tujuan jangka pendek dan panjang serta merencanakan teknik dan strategi untuk mencapai tujuan tersebut. Pendapat yang sama juga dikemukakan oleh Ngalim Purwanto,( 2012:15) bahwa dalam membuat perencanaan 
sebagai berikut: a) menentukan dan merumuskan tujuan yang hendak dicapai, b) meneliti masalah-masalah atau pekerjaan-pekerjaan yang akan dilakukan, c) mengumpulkan data dan informasi yang diperlukan, d) menentukan tahap-tahap atau rangkaian tindakan, e) merumuskan bagaimana masalah-masalah tersebut akan dipecahkan, dan bagaimana pekerjaan-pekerjaan itu akan diselesaikan.

Selain perencanaan, kepala sekolah sebagai administrator dituntut mampu menggerakan organisasi sekolah dengan baik. Struktur organisasi dipastikan dapat berjalan secara efektif sesuai dengan keahlian dan tugas pokok masing-masing anggota organisasi seperti pembagian kerja, otoritas dan tanggung jawab, sentralisasi, dan top down atau kepala sekolah sebagai komamdo pimpinan di sekolah tersebut. Dalam penelitian tersebut ditemukan bahwa secara keseluruhan guru-guru yang mengajar di sekolah tersebut sesuai dengan keahlian bidang studi masing-masing. Kepala sekolah memberikan otoritas dan tanggung jawab kepada guru untuk menjalankan tugas pokoknya terkait dengan proses pembelajaran maupun non pembelajaran sesuai dengan keahlian masing-masing agar tujuan organisasi dapat terwujud secara optimal.

Temuan di atas sesuai dengan pendapat para ahli diantaranya pendapat Syaiful Sagala (2012:95) bahwa mengorganisasikan berarti: (1) menentukan sumberdaya dan kegiatan yang dibutuhkan untuk mencapai tujuan organisasi, (2) merancang dan mengembangkan kelompok kerja yang berisi orang yang mempu membawa organisasi pada tujuan, (3) menunggaskan seseorang atau kelompok orang dalam suatu tanggung jawab dan fungsi tertentu, (4) mendelegasikan wewenang kepada individu yang berhubungan dengan keluwesan melaksankan tugas. Pendapat yang sama juga di kemukakan Edgar Schein (dalam Soebagio Atmodiwirio, 2010:101) bahwa organisasi adalah koordinasi yang rasional dari aktivitas-aktivitas sejumlah orang untuk mencapai beberapa tujuan yang jelas melalui pembagian kerja, dan fungsi, serta melalui jenjang wewenang dan tanggung jawab. Dalam mewujudkan efektifitas struktur organisasi, ada lima prinsip struktural yang harus difungsikan dengan baik sebagai berikut: a) prinsip pembagian kerja, yaitu dengan adanya spesialisasi atau ahlinya, merupakan langkahlangkah paling baik dalam memanfaatkan orang untuk dapat menjalankan tugasnya dengan efektif dan efisien, b) prinsip satu arah, yaitu sebuah keharusan menunjuk top manager untuk mengkoordinasikan aktivitas-aktivitas yang berkaitan, mengingat komplekstisitas pembagian kerja, sehingga tidak terjadi duplikasi dalam menjalankan 
perkerjaan, c) prinsip sentralisasi, yaitu menciptakan keseimbangan antara sentralisasi dengan desentralisasi. Keseimbangan tersebut tidak dapat ditentukan tanpa memperhatikan kecakapan para manajer yang ditunjuk untuk mengoordinasi departemen, d) prinsip otoritas dan tanggung jawab, yaitu perlu ada kaitan antara tanggung jawab para manajer dan otoritas yang mereka lakukan, e) prinsip rantai komando, yaitu rantai bertingkat dari atasan yang memegang peranan otoritas tertinggi, sampai dengan hierarki yang paling rendah. Komunikasi dari herarki yang paling rendah harus melewati setiap atasan dalam rantai komando, dan sebaliknya, komunikasi dari puncak atasan harus melewati setiap bawahan sampai komunikasi tersebut mencapai tingkat kesesuaian (Siswanto, 2000:98-99)

Perencanaan dan pengorganisasian guru tidak akan berjalan efektif tanpa ada koordinasi. Kepala sekolah harus paiawai dalam berkoordinasi di organisasi yang dipimpinnya. Koordinasi dapat menghindarkan kemungkinan terjadinya persaingan yang tidak sehat, dan atau kesimpangsiuran dalam tindakan. Dengan koordinasi yang baik, semua bagian, dan personel dapat bekerja sama menuju ke satu arah tujuan yang telah ditetapkan.

Berdasarkan pengamatan peneliti, ada 3 (tiga) yang dilakukan oleh kepala sekolah SMP Muhammadiyah 17 Ciputat dalam mengimplementasikan koordinasi di sekolah tersebut: a) membangun komunikasi dengan guru-guru secara baik dan intensif seperti dalam rapat yang dilaksanakan setiap bulannya dengan tujuan menghindari kesimpangsiuran dalam tindakan, b) mengarahkan dan motivasi seperti kepala sekolah mendengarkan pendapat guru-guru, diskusi kecil, mendatangkan motivator, dan mengundang para ahlidengan tujuan untuk menghindari pekerjaan yang tidak relevan di sekolah tersebut, c) menyelesaikan konflik dengan pihak ekstern (penghubungan antar sekolah, pemerintah, dinas pendidikan) dan institusi-institusi terkait. Temuan di atas sesuai dengan pendapat para ahli diantaranya Yati Siti Mulyati dan Aan Komariah (2006:96) berpendapat bahwa koordinasi atau pengendalian adalah proses untuk memastikan aktivitas sebenarnya sesuai dengan aktivitas yang direncanakan sebelumnya. Proses pengendalian atau koordinasi melibatkan beberapa elemen yaitu: (a) menetapkan standar kerja, (b) mengukur kerja, (c) membandingkan unjuk kerja dengan standar yang telah ditetapkan, (d) mengambil tindakan korektif saat terditeksi penyimpangan. Pendapat yang sama juga dikemukakan oleh Husaini Usman 
(2006:363) berpendapat koordinasi adalah proses mengintegrasikan (memadukan), mensinkronisasikan, dan menyederhanakan pelaksanaan tugas yang terpisah-pisah secara terus menerus untuk mencapai tujuan secara efektif dan efisien.

\section{SIMPULAN}

Berdasarkan hasil temuan dan pembahasan temuan penelitian yang dikemukakan pada pembahasan di atas dapat disimpulkan bahwa peran kepala sekolah sebagai administrator di SMP Muhammadiyah 17 Ciputat telaksana cukup efektif. Hal tersebut dapat dilihat adanya perencanaan program-progam sekolah yang melibatkan semua stakehorders sekolah, mengorganisasikan guru dengan memberikan tugas pokok dan tanggung jawab guru sesuai dengan keahlian bidang studi masing-masing, dan koordinasi skema organisasi dengan membangun komunikasi dalam pertemuanpertemuan rutin, rapat evaluasi, pengarahan dan motivasi dengan tujuan untuk menghindari persaingan kurang sehat dan kesimpangsiuran dalam informasi dan tindakan

\section{SARAN}

Penelitian ini perlu ditindak lanjuti agar pendidikan tingkat Sekolah Menengah Pertama dan sederajat lebih mengoptimalkan adminstrasi sekolah sehingga kegiatankegiatan sekolah dapat terlaksana dengan baik dan terarah sehingga output atau luarannya adalah guru-guru yang profesional dan potensial yang akan menghasilkan siswa/siswi yang cerdas, kompeten, dan berkarakter.

\section{DAFTAR PUSTAKA}

Athoillah, M. Anton. 2010. Dasar-dasarManajemen. Bandung: Pustaka Setia.

Atmodiwirio,Soebagio.2000.Manajemen Pendidikan Indonesia. Jakarta: Ardadizya Jaya.

Castetter, William B. 1981, The Personnel Function in Educational Administration. New York : Macmillan Publishing Company.

Dessler, Gari. 1997. Management Leading People and Organization. London: Prentice Hall.

Dessler, Garri. 2001. Management, Leading People and Organization. London: Prentice Hall. 
Research and Development Journal Of Education

Vol. 4 No. 2 April 2018

ISSN 2406-9744

Irham,Fahmi. 2011. Manajemen, Teori, KasusdanSolusi. Bandung: Alfabeta.

Ivancevich, Gibson dan Donnelly. 1997 Organization, Behavior, Structure and Processes. United States of America: Times Mirror Higher Education Group.

Miller, Alex.1998. Strategic Management, Third Edition. Boston: Irwin/McGraw-Hill.

Milstein, Mike M. dan Belasco, James A. 2001, Educational Administration and the Behavioral Sciences : A Systems Perspective. Boston: Allin And Bacon.

Mulyati, Yati dan Komariah Aam. 2010. Tim Dosen Administrasi Pendidikan Universitas Pendidikan Indonesia.

Prihatin, Eka. 2011. Teori Administrasi Pendidikan. Bandung: Alfabeta.

Purwanto, Ngalim. 2012. AdministrasidanSupervisiPendidikan. Bandung: Remaja Rosdakarya.

Sagala, Syaiful. 2009. Administrasi Pendidikan Kontemporer. Bandung: Alfabeta.

Siswanto. 2000. Manajemen SDM dalam Organisai Publik dan Bisnis. Bandung: alfabeta.

Suhardan, Dadang. 2010. Supervisi Profesional, Layanan dalam Meningkatkan Mutu Pembelajaran di Era Otonomi Daerah. Bandung: Alfabeta. 